\title{
SELF ESTEEM KORBAN BULLYING (Survey Kepada Siswa-siswi Kelas VII SMP Negeri 270 Jakarta Utara)
}

\author{
Stefi Gresia ${ }^{1}$ \\ Dr. Gantina Komalasari, M. Psi ${ }^{2}$ \\ Karsih, M. Pd ${ }^{3}$
}

\begin{abstract}
Abstrak
Tujuan penelitian ini adalah untuk memperoleh gambaran mengenai self esteem korban bullying yang duduk di kelas VII. Penelitian ini dilakukan di SMP Negeri 270 Jakarta Utara dengan populasi sebanyak 168 siswa-siswi kelas VII. Pengambilan sampel dilakukan dengan teknik Purposive Sampling, diperoleh 39 siswa korban bullying dengan kategori tinggi. Metode penelitian yang digunakan dengan studi deskriptif. Instrumen pada penelitian ini berupa kuesioner tentang bullying yang dikembangkan oleh Sullivan dan Self Esteem yang diadaptasi Stanley Coopersmith. Setelah dilakukan uji coba, untuk angket bullying, didapatkan hasil 31 item valid dan 4 item drop dengan nilai reliabilitas 0.712 dan self esteem didapatkan hasil 55 item valid dan 3 item drop dengan reliabilitas uji coba 0.739. Hasil dari penelitian ini menunjukkan bahwa tingkat self esteem siswa yang menjadi korban bullying 46\% siswa berada pada kategori sedang, 31\% siswa berada pada kategori rendah dan $23 \%$ siswa berada pada kategori tinggi. Untuk mean per komponen, jumlah tertinggi diperoleh dari komponen self esteem umum sebesar 39 atau 43,33\% selanjutnya self esteem akademis dengan sebesar 12 atau 42,30\%, lalu self esteem sosial dengan jumlah 11 atau 41,67\% dan terendah adalah self esteem keluarga dengan jumlah 10 atau 40\%. Penelitian ini ditujukan bagi guru Bimbingan dan Konseling serta pihak sekolah, hendaknya memberikan layanan informasi kepada siswa-siswi untuk mengembangkan harga diri. Langkah ini juga dapat ditempuh dengan memberikan layanan konseling kelompok kepada siswa-siswi yang menjadi korban bullying dan bekerjasama dengan pihak sekolah, seperti wali kelas dengan tujuan untuk menciptakan lingkungan belajar yang kondusif dan nyaman.
\end{abstract}

Kata kunci : Self esteem, Bullying, Korban Bullying

\section{Pendahuluan}

Remaja adalah individu yang sedang mengalami peralihan dari masa anak menuju masa dewasa. $\mathrm{Pa}-$ da masa ini, remaja mengalami perubahan yang pesat dalam berbagai aspek perkembangan, baik aspek biologis, psikologis, dan sosial. Remaja akan meng- alami masa dimana mereka belum mampu mengelola emosinya dengan baik. Kondisi emosinya yang labil, marah-marah berlebihan, atau tiba-tiba sedih, dan kurang mampu mengendalikan emosi dapat memicu masalah dalam keseharian mereka. Masalahmasalah tersebut antara lain kesulitan belajar, pe-

1 Mahasiswa Jurusan Bimbingan dan Konseling FIP UNJ, Stefigresia@gmail.com

2 Dosen Bimbingan dan Konseling FIP UNJ,

3 Dosen Bimbingan dan Konseling FIP UNJ, 
nyalahgunaan obat terlarang, melakukan tindakan kekerasan, dan perilaku menyimpang lainnya.

Masa remaja pada umumnya juga memiliki perilaku yang positif yang dapat ditonjolkan, namun yang dikhawatirkan muncul pada masa remaja adalah kecenderungan perilaku negatif lainnya antara lain berupa ancaman, pemukulan, pemalakan, dan tindak kekerasan lainnya terhadap orang lain. Tindakan ini dapat dilakukakan oleh remaja, baik secara individu maupun berkelompok dan dapat dilakukakan secara berulang-ulang. Tindakan ini sering disebut dengan istilah Bullying.

Pada umumnya, para korban bullying tidak mampu membela atau mempertahankan dirinya karena lemah secara fisik atau bahkan mental. Bullying memiliki berbagai macam jenis dan wujud yang berbeda-beda, akan tetapi secara umum praktik bullying dapat dikelompokkan menjadi tiga kategori, yaitu bullying fisik, verbal maupun psikologis.

Bagi setiap korban bullying akan mengalami dampak yang beraneka ragam, salah satunya ialah remaja akan memiliki harga diri negatif dan akan memandang dirinya sebagai orang yang tidak berharga. Rasa tidak berharga tersebut dapat tercermin pada rasa tidak berguna dan tidak memiliki kemampuan yang baik dari segi akademik, interaksi sosial, keluarga dan keadaan fisiknya. Namun, harga diri yang negatif ini dapat membuat remaja merasa tidak mampu menjalin hubungan yang baik dengan teman sebayanya sehingga menjadi mudah sensitif.

Menurut Coopersmith, self esteem (harga diri) adalah penilaian yang dibuat seseorang dan biasanya mengenai dirinya sendiri. Selanjutnya diekspresikan dalam sikap menerima atau menolak dirinya sendiri dan mengindikasikan tingkat keperca-yaan dirinya untuk menjadi kompeten, penting, sukses dan berharga. Tingkat self esteem yang dimiliki tiap individu akan mempengaruhi motivasi untuk mendorong seseorang mencapai keberhasilan dalam bidang tertentu, mempengaruhi rasa puas terhadap suatu prestasi yang telah diraih. Namun, apabila anak memiliki tingkat harga diri yang negatif atau rendah, anak akan memandang bahwa dirinya tidak berharga dan itu dapat tercermin pada perasaan tidak berguna yang dimiliki anak.

Berdasarkan hal-hal tersebut, maka rumusan masalah dalam penelitian ini ialah "Bagaimana Self
Esteem Korban Bullying Siswa-siswi Kelas VII di SMP Negeri 270 Jakarta Utara?". Tujuan diadakan penelitian ini yaitu mengetahui gambaran self esteem korban bullying kelas VII di SMPN 270 Jakarta Utara.

\section{Kajian Teori \\ Hakikat Self Esteem}

Menurut Coopersmith, self esteem (harga diri) adalah penilaian yang dibuat seseorang dan biasanya mengenai dirinya sendiri. Selanjutnya diekspresikan dalam sikap menerima atau menolak dirinya sendiri dan mengindikasikan tingkat kepercayaan dirinya untuk menjadi kompeten, penting, sukses dan berharga. Coopersmith juga menyatakan bahwa terdapat empat aspek utama dalam harga diri, yaitu harga diri umum, sosial, keluarga dan akademis.

Coopersmith membagi tingkatan self-esteem menjadi tiga kategori, yaitu self seteem tinggi, dimana individu dengan harga diri tinggi menunjukkan bahwa individu yang memiliki harga diri tinggi adalah seseorang yang merasa bahwa dirinya dinilai sebagai orang yang berharga, penting dan layak dihormati oleh orang-orang disekitarnya. Kedua adalah self esteem sedang, dimana individu yang termasuk dalam karakteristik ini memiliki karakteristik yang relatif sama dengan self esteem tinggi, namun yang membedakan ialah terkadang merasa ragu-ragu dengan penghargaan diri yang diterimanya. Ketiga adalah self esteem rendah, dimana individu memiliki perasaan ditolak, ragu-ragu, merasa tidak berharga, merasa terisolasi, tidak memiliki kekuatan, tidak pantas dicintai, tidak mampu mengekspresikan diri, tidak mampu mempertahankan diri sendiri, dan merasa terlalu lemah untuk melawan kelemahan mereka sendiri. Selain itu, individu dengan harga diri rendah cenderung merasa kurang percaya diri, memiliki kekhawatiran dalam mengungkapkan ide-ide yang tidak biasa, dan tidak aman dalam interaksi sosial.

\section{Hakikat Bullying}

Bullying adalah tindakan sadar dan dilakukan secara sengaja dari agresi atau manipulasi oleh seseorang atau beberapa orang terhadap yang lain. Tindakan bullying mencakup beberapa hal yaitu bertujuan melukai, adanya ketidakseimbangan kekuatan atau kekuasaan. Seringkali tindakan bullying dilaku- 
kan secara sistematis dan terencana, terjadi berulang dalam jangka waktu tertentu dan pengalaman disakiti yang didapat korban dapat berupa fisik atau psikis.

\section{Bentuk-bentuk Bullying}

Menurut Sullivan, bullying terbagi dalam tiga bentuk, yaitu:

a. Bullying Fisik yang merupakan jenis bullying yang terlihat dengan indra pengelihatan karena terjadi sentuhan fisik antra pelaku dengan korban, seperti memukul, menendang, mendorong, atau melakukan sesuatu yang menyebabkan korban terluka ataupun terjatuh

b. Bullying verbal yang dapat terdeteksi karena tertangkap oleh indra pendengar, seperti mencela, menghina, mengintimidasi, mengancam melalui telepon, ancaman kekerasan, pemerasa, menyebabkan rumor negatif, penghinaan ras, cyber bullying, memfitnah, dan sebagainya.

c. Bullying psikologis dimana jenis bullying seperti ini tidak terlihat oleh indra pengelihatan dan pendengaran, seperti memandang sinis, memandang dengan penuh ancaman, mendiamkan, mengucilakn, mencibir, memandang dengan rendah, dan meneror melalui pesan pendek maupun email.

\section{Dampak Bullying}

Dampak bullying adalah konsekuensi merugikan yang terjadi dalam konteks sosial dapat mempengaruhi satu orang atau paling tidak semua pihak yang ditindas. R. Djuwita berpendapat bahwa dampak yang dialami korban bullying, antara lain harga diri rendah, gangguan kecemasan, mengurung diri, sulit menyesuaikan diri di dalam lingkungannya, depresi bahkan bunuh diri. Pendapat yang sama juga dikemukakan oleh Keith Sullivan, yaitu dampak yang dirasakan oleh korban bullying ialah harga diri rendah, cemas, introvert, lebih suka menyendiri, sedikit memiliki teman dekat, memiliki keinginan untuk pindah sekolah, mimpi buruk, depresi, hingga muncul keinginan untuk bunuh diri.

\section{Metodologi Penelitian}

Penelitian ini dilakukan di SMP Negeri 270 Jakarta Utara. Waktu penelitian dilaksanakan dari bulan Februari hingga Mei 2014 . Penelitian ini meng- gunakan metode survey dengan memakai studi deskriptif. Metode ini dipakai untuk mendapatkan gambaran atau uraian suatu keadaan sejelas mungkin tanpa ada perlakuan terhadap objek yang diteliti.

Populasi pada penelitian ini yaitu seluruh siswa kelas VII di SMP Negeri 270 Jakarta yang berjumlah 168 siswa. Teknik pengambilan sampel yang dilakukan adalah dengan teknik purposive sampling yaitu sampel berdasarkan karakteristik tertentu yang dianggap mempunyai hubungan dengan karakteristik populasi ebelumnya, yaitu siswa-siswi kelas VII yang menjadi korban bullying. Sampel dari penelitian ini adalah siswa-siswi yang menjadi korban bullying yang masuk dalam klasifikasi tinggi yaitu dengan frekuensi sebanyak 39 siswa-siswi. Teknik pengumpulan data yang digunakan yaitu self esteem inventory untuk variable self esteem dan angket bullying untuk menetapkan sampel yang menjadi korban bullying.

Untuk uji coba instrumen dalam penelitian ini digunakan pengujian validitas dan reliabilitas menggunakan aplikasi SPSS. Pengujian validitas hasil uji coba self esteem inventory diperoleh 55 item dinyatakan valid dan 3 item dinyatakan drop dengan hasil reliabilitas sebesar 0,739 . Untuk pengujian validitas hasil uji voba angket bullying, diperoleh 31 item dinyatakan valid dan 4 item dinyatakan drop dengan hasil reliabilitas sebesar 0,712.

\section{Hasil dan Pembahasan \\ Self Esteem Korban Bullying}

Berdasarkan hasil perhitungan, menyatakan bahwa banyaknya korban bullying secara keseluruhan memiliki skor mean $(\mu)$ 85,52 dan standar deviasi $(\sigma)$ sebesar 4,92. Bila digolongkan dalam tiga kategorisasi tingkat self esteem , maka dapat dilihat pada tabel 4.1 dan grafik 4.1 sebagai berikut:

Tabel 4.1

Kategorisasi Self Esteem Korban Bullying

\begin{tabular}{|c|c|c|c|}
\hline Kategorisasi & $\begin{array}{c}\text { Rentang } \\
\text { Skor }\end{array}$ & Frekuensi & Persentase \\
\hline Tinggi & $\geq 90,74$ & 9 & $23 \%$ \\
\hline Sedang & $83-91$ & 18 & $46 \%$ \\
\hline Rendah & $\leq 80.9$ & 12 & $31 \%$ \\
\hline \multicolumn{2}{|c|}{ Jumlah } & 39 & $100 \%$ \\
\hline 85,52 & $\Sigma$ & 4,92 & \\
\hline
\end{tabular}




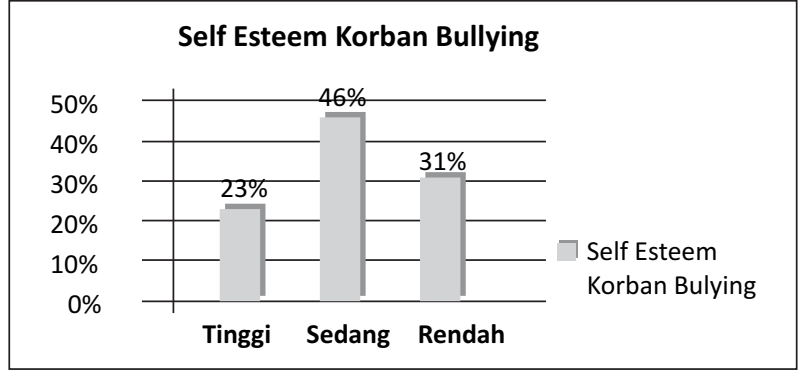

Grafik 4.1 Tingkat Self Esteem Korban Bullying Siswa kelas VII SMP Negeri 270 Jakarta Utara

Berdasarkan tabel dan grafik, diperoleh tiga kategori tingkat self esteem remaja korban bullying kelas VII di SMP Negeri 270 Jakarta, yaitu kategori tinggi sebesar 23\% atau sebanyak 9 orang, kategori sedang sebesar $46 \%$ atau sebanyak 18 orang dan kategori rendah sebanyak $31 \%$ atau sebanyak 12 orang.

\section{Mean Skor $(\mu)$ Self Esteem Per Komponen}

Untuk menggambarkan keseluruhan self esteem dengan mean skor pada tiap komponen sehingga menggambarkan komponen yang terendah pada remaja korban bullying kelas VII di SMP Negeri 270 Jakarta Utara dapat dilihat pada tabel 4.2 dan grafik 4.2 sebagai berikut:

Tabel 4.2

Mean Skor $(\mu)$ Per Komponen

\begin{tabular}{|c|c|}
\hline $\begin{array}{c}\text { Komponen } \\
\text { Self Esteem }\end{array}$ & $\begin{array}{c}\text { Mean Skor } \\
(\boldsymbol{\mu})\end{array}$ \\
\hline Umum & 39 \\
\hline Sosial & 11 \\
\hline Keluarga & 10 \\
\hline Akademis & 12 \\
\hline
\end{tabular}

Mean Skor $(\mu)$ Self Esteem Per Komponen

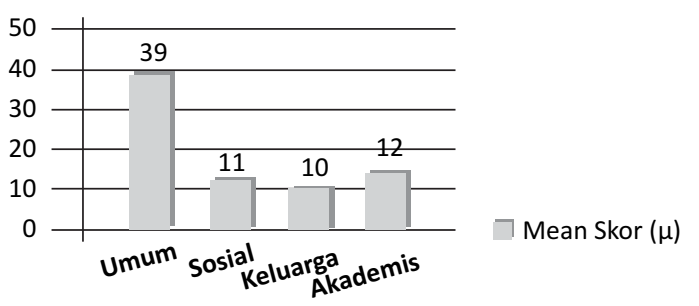

Grafik 4.2 Mean Skor Per Komponen Self Esteem Siswa Remaja Kelas VII Korban Bullying SMP Negeri 270 Jakarta Utara

Tabel dan grafik 4.2 menyatakan bahwa kompo- nen umum memiliki grafik mean skor yang paling tinggi di antara grafik yang lain, yaitu sebanyak 39 dengan persentase sebesar 43,33\%, komponen self esteem akademis dengan mean skor sebesar 12 dengan persentase sebesar $42,30 \%$, komponen self esteem sosial, dengan jumlah mean skor sebesar 11 dengan persentase sebesar $41,67 \%$ dan komponen self esteem keluarga dengan skor 10 dengan persentase sebesar $40 \%$.

\section{Self Esteem Remaja Korban Bullying Tiap \\ Komponen}

Berikut ini adalah tabel dan grafik mengenai gambaran tingkat self esteem siswa-siswi yang menjadi korban bullying

Tabel 4.3 Self Esteem Remaja Korban Bullying Tiap Komponen

\begin{tabular}{|c|c|c|c|c|}
\hline Klasifikasi & Umum & Sosial & Keluarga & Akademis \\
\hline Tinggi & $23 \%$ & $23 \%$ & $38 \%$ & $49 \%$ \\
\hline Sedang & $56 \%$ & $28 \%$ & $24 \%$ & $31 \%$ \\
\hline Rendah & $21 \%$ & $49 \%$ & $38 \%$ & $20 \%$ \\
\hline
\end{tabular}

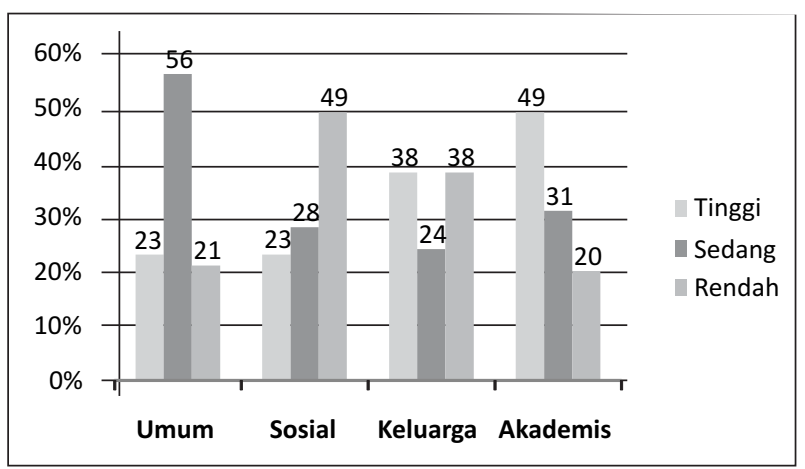

Grafik 4.3 Self Esteem Remaja Korban Bullying Per Komponen

Pada tabel dan grafik 4.3 menyatakan bahwa komponen tertinggi yang dimiliki oleh siswa-siswi yang menjadi korban bullying terdapat pada komponen akademis dengan persentase sebesar $49 \%$ di mana siswa-siswi yang menjadi korban bullying mampu menunjukkan usaha yang tinggi dari masing-masing individu bahwa mereka mampu bersaing dalam hal akademis di sekolah. Selanjutnya tertinggi kedua adalah komponen keluarga dengan persentase sebesar 38\% yang menunjukkan bahwa terdapat pengaruh yang seimbang antara kedekatan orangtua terhadap anak. Untuk komponen sosial dan umum memiliki persentase yang sama yaitu sebesar $23 \%$ yang 
menunjukkan bahwa siswa-siswi yang menjadi korban bullying mampu melakukan penilaian terhadap dirinya sendiri dan mampu menunjukkan kemampuannya berhubungan dengan lingkungan sosial meskipun pernah mendapatkan perlakuan yang tidak menyenangkan dari lingkungan sekitar.

Terdapat pula komponen yang memiliki persentase terendah, yaitu terdapat pada komponen sosial dengan persentase sebesar $49 \%$ dimana para siswasiswi yang menjadi korban bullying merasa sulit untuk dapat menunjukkan kepeduliannya terhadap orang lain, bahkan sulit untuk memulai hubungan dengan lingkungan baru. Dapat dilihat bahwa kurangnya rasa kesukaannya terhadap orang lain maupun keikutsertaannya dalam aktivitas lain.

\section{Kesimpulan dan Saran}

Setelah seluruh tahap penelitian dilaksanakan, didapatkan hasil penelitian dan analisis hasil penelitian kepada siswa-siswi kelas VII di SMP Negeri 270 Jakarta Utara, maka dapat disimpulkan bahwa:

1. Dari keseluruhan siswa yang menjadi korban bullying, terdapat tiga klasifikasi yaitu tinggi, sedang dan rendah. Para korban bullying secara keseluruhan memiliki klasifikasi tingkat self esteem sedang dengan persentase sebesar $46 \%$ dimana individu yang masuk dalam klasifikasi ini adalah individu yang memiliki harga diri dengan penerimaan, pertahanan dan pemahaman diri yang cukup baik. Sedangkan klasifikasi self esteem rendah mendapatkan persentase sebesar $31 \%$ dan self esteem tinggi mendapatkan persentase sebesar 23\%

2. Mean skor yang didapat dari tiap komponen self esteem, terdapat mean skor yang paling rendah yaitu terdapat pada komponen self esteem keluarga dengan skor 10 dan mean skor tertinggi terdapat pada komponen self esteem umum dengan skor 39
3. Dari keseluruhan siswa kelas VII di SMP Negeri 270 Jakarta Utara, terdapat 39 siswa remaja yang menjadi korban bullying yang termasuk dalam klasifikasi tinggi dengan persentase sebesar 23\% yang masuk kedalam rentang skor $\geq 16$.

\section{Saran}

1. Bagi para siswa-siswi korban bullying yang sudah diketahui memiliki self esteem rendah hendaknya mendapatkan penanganan dari pihak yang lebih profesional sesuai dengan dampak yang ditimbulkan oleh para korban bullying tersebut, seperti guru Bimbingan dan Konseling di sekolah hingga psikolog.

2. Guru Bimbingan dan Konseling dan pihak sekolah di SMP Negeri 270 Jakarta Utara hendaknya memberikan layanan informasi kepada siswasiswi untuk mengembangkan harga diri, antara lain harga diri yang positif, penerimaan diri, serta bertanggung jawab terhadap dirinya sendiri. Selain itu, guru Bimbingan dan Konseling juga dapat memberikan konseling kelompok kepada siswa-siswi yang menjadi korban bullying dan bekerjasama dengan pihak sekolah, seperti wali kelas untuk terlibat aktif dengan tujuan untuk menciptakan lingkungan belajar yang kondusif dan nyaman.

3. Bagi mahasiswa atau peneliti selanjutnya, penelitian ini hanya mengambil subjek kepada siswasiswi kelas VII SMP Negeri 270 Jakarta Utara. Untuk peneliti selanjutnya direkomendasikan untuk meneliti setiap kelas dan jenjang pendidikan yang berbeda, sehingga gambaran yang didapat lebih optimal. Peneliti selanjutnya juga diharapkan dapat mengembangkan penelitian dengan membedakan harga diri siswa-siswi berdasarkan jenis kelamin, latar belakang sosial ekonomi, karakteristik orangtua maupun ras. 


\section{Daftar Pustaka}

Aida Arga Putri. (2005). Skripsi Gambaran Self Esteem Remaja Pelaku Bullying. Jakarta: Universitas Indonesia

Barbara Coloroso. STOP BULLYING!. Jakarta: Serambi Ilmu Semesta, 2007 (Terjemahan)

Dr. H. Syamsu Yusuf LN., M. Pd. (2007). Psikologi Perkembangan Anak dan Remaja. Bandung: PT Remaja Rosdakarya

Keith Sullivan. (2000). The Anti Bullying Handbook Secondary Schools. Australia: Oxford University Press
Stanley Coopersmith. (1967). The Antecedents of Self Esteem. Freeman Company: San Francisco

Suharsimi Arikunto. (2002). Prosedur Penelitian Suatu Pendekatan Praktek. Jakarta: Rineka Cipta

Sugiyono. (2011). Metode Penelitian Kuantitatif, Kualitatif dan R\&D. Bandung: Alfabeta

Yayasan SEJIWA. (2008). Bullying-Mengatasi Kekerasan di Sekolah dan Lingkungan Sekitar Anak. Jakarta: Grasindo 